\title{
Factors affecting the rate of breakdown of bacterial protein in rumen fluid
}

\author{
BY R. J. WALLACE AND CAROL A. MCPHERSON \\ Rowett Research Institute, Bucksburn, Aberdeen AB2 9SB
}

(Received 1 August $1986-$ Accepted 1 April 1987)

\begin{abstract}
1. The cellular proteins of Butyrivibrio fibrisolvens, Lactobacillus casei, Megasphaera elsdenii, Selenomonas ruminantium and Streptococcus bovis were labelled by growth in the presence of $\mathrm{L}-\left[{ }^{14} \mathrm{C}\right]$ leucine, and the breakdown of labelled protein was measured in incubations of these bacteria with rumen fluid to which unlabelled 5 mM-Lleucine was added. The rate of protein breakdown was estimated from the rate of release of radioactivity into acid-soluble material.

2. Protein breakdown occurred at different rates in different species. The mean rates for B. fibrisolvens, L. casei, $M$. elsdenii, Sel. ruminantium and Str. bovis were $28 \cdot 6,18 \cdot 1,17 \cdot 7,10.5$ and $5.3 \% / \mathrm{h}$ respectively in samples of strained rumen fluid (SRF) with different protozoal populations. Rates of $3 \% / \mathrm{h}$ or less were found in SRF from ciliate-free sheep or in faunated SRF from which protozoa had been removed by centrifugation. Further removal of mixed rumen bacteria had little effect. Suspensions of washed protozoa degraded bacterial protein at rates which were of the same order as those found in SRF.

3. The rate of breakdown of bacterial protein in different samples of SRF tended to increase as the numbers of small entodiniomorphid protozoa increased. The numbers of larger entodiniomorphs and holotrichs had no obvious influence on this rate.

4. Autoclaved and u.v.-treated bacteria were generally no different from live bacteria in their susceptibility to breakdown in SRF from faunated sheep, indicating that endogenous protein turnover was not a significant cause of bacterial protein catabolism.

5. The rate of bacterial protein breakdown was unrelated to the proteolytic activity of SRF.

6. It was concluded that predation by small protozoa is by far the most important cause of bacterial protein turnover in the rumen, with autolysis, other lytic factors and endogenous proteolysis being of minor importance.
\end{abstract}

Various isotope-labelling experiments have demonstrated the extensive nature of protein turnover in the rumen (Demeyer \& Van Nevel, 1979; Leng \& Nolan, 1984). Protein turnover as observed in the mixed population includes both endogenous protein turnover within individual organisms, which occurs without lysis and is a normal activity of all bacteria (Pine, 1972; Hobson \& Wallace, 1982), and protein breakdown and resynthesis resulting from cell lysis. Engulfment and digestion of bacteria by protozoa is a factor widely implicated in the latter type of turnover (Jarvis, 1968; Lindsay \& Hogan, 1972; Demeyer \& Van Nevel, 1979; Coleman, 1979, 1980), but others include infection by bacteriophages (Hoogenraad et al. 1967; Hoogenraad \& Hird, 1970; Orpin \& Munn, 1974) and anaerobic mycoplasmas (Robinson \& Hungate, 1973), autolysis (Hoogenraad \& Hird, 1970) and lysis of undefined soluble lytic factors (Jarvis, 1968).

Since a decrease in bacterial protein turnover in the rumen would be expected to increase the net microbial production of protein flowing to the abomasum, this would be beneficial to the protein nutrition of the ruminant animal if the animals were protein deficient. The present experiments were therefore undertaken to evaluate the impact of various factors affecting protein breakdown in different species of rumen bacteria, with a view to identifying and possibly eliminating the cause of this wasteful metabolism.

\section{METHODS}

Animals and diets

Cow no. 951 was a rumen-fistulated non-lactating Friesian, 4 years of age, which received $2.0 \mathrm{~kg}$ hay, $2.4 \mathrm{~kg}$ grass cubes and $2.4 \mathrm{~kg}$ concentrate (eight parts maize, two parts oats, two 
parts bran, one part linseed cake, one part white fish meal, with added vitamin supplement; Eadie \& Gill, 1971) daily, divided into two equal meals.

The sheep used were mature rumen-fistulated animals. They received twice daily a diet consisting of two parts hay and one part of the same concentrate as the cow (sheep nos. $447,521,655$ and 914) or a diet of two parts hay and one part grass cubes (sheep nos. 288, 4061 and 3348), fed approximately to maintenance. Sheep nos. 72 and 92, which had been isolated from birth and were free of ciliate protozoa, also had rumen fistulas and received the hay plus concentrate diet twice daily.

All surgery was conducted under general anaesthesia and with normal aseptic precautions.

\section{Sampling and fractionation of rumen fluid}

Samples of rumen fluid were removed $3-5 \mathrm{~h}$ after the morning ( 08.00 hours) feeding and strained through four layers of muslin, maintaining the temperature at $39^{\circ}$ throughout. Protozoa were removed by centrifuging strained rumen fluid (SRF) twice at $1000 \mathrm{~g}$ for $10 \mathrm{~min}$, leaving protozoa-free rumen fluid (PFRF). Cell-free rumen fluid (CFRF) was obtained by centrifuging SRF twice at $49000 \mathrm{~g}$ for $15 \mathrm{~min}$. Washed protozoa were prepared from SRF by differential sedimentation and washing (Whitelaw et al. 1983).

\section{Preparation of labelled bacteria}

Butyrivibrio fibrisolvens JW11, Lactobacillus casei (NCIB 7473), Megasphaera elsdenii LC1, Selenomonas ruminantium Z108 and Streptococcus bovis $\mathrm{C} 277$ were maintained on medium no. 2 of Hobson (1969) and labelled by growing overnight at $39^{\circ}$ in a medium $(7 \mathrm{ml})$ containing the same minerals, clarified rumen fluid, glucose, maltose, sodium bicarbonate and cysteine as medium no. 2, with added vitamins (Scott \& Dehority, 1965) and $0.4 \mu \mathrm{Ci}$ $\mathrm{L}-\left[\mathrm{U}-{ }^{14} \mathrm{C}\right]$ leucine $(58 \mathrm{Ci} / \mathrm{mol}), \mathrm{L}-\left[\mathrm{U}-{ }^{14} \mathrm{C}\right]$ tyrosine $(513 \mathrm{Ci} / \mathrm{mol})$, or $\mathrm{L}-\left[\mathrm{U}-{ }^{14} \mathrm{C}\right]$ phenylalanine $(0.9 \mathrm{Ci} / \mathrm{mol})$. Bacteria were harvested by centrifugation, and washed once in fresh unlabelled medium. Anaerobic ( $100 \%$ carbon dioxide) conditions were maintained throughout unless otherwise specified.

In experiments to investigate the effects of cell death, labelled bacteria were killed by autoclaving at $121^{\circ}$ for $15 \mathrm{~min}$, or by treating with u.v. light by pouring a culture $(7 \mathrm{ml})$ into a sterile Petri dish and irradiating the dish with a u.v. lamp ( $28 \mathrm{~W}$ Mineralight; Ultra-violet Products Inc., San Gabriel, California) for $5 \mathrm{~min}$ at a distance of approximately $100 \mathrm{~mm}$. The latter treatment resulted in a $99 \%$ kill of Sel. ruminantium.

\section{Rate of bacterial protein degradation}

Portions ( $2.5 \mathrm{ml}$ ) of SRF, PFRF, CFRF, washed protozoa, or phosphate buffer were added to pellets from $1.75 \mathrm{ml}$ of the labelled bacterial culture, mixed and incubated under $\mathrm{CO}_{2}$ in Hungate tubes in a shaking water-bath at $39^{\circ}$. Samples $(0.4 \mathrm{ml})$ were removed at $1 \mathrm{~h}$ intervals up to $4 \mathrm{~h}$ into tubes containing $0.1 \mathrm{ml}$ trichloroacetic acid $(250 \mathrm{~g} / \mathrm{l})$, which were then centrifuged $(12000 \mathrm{~g}, 3 \mathrm{~min})$ and duplicate samples of the supernatant fluid were counted by liquid-scintillation spectrometry. The extent of protein breakdown at each incubation time was calculated from the acid-soluble disintegrations/min (dpm) and expressed as a percentage of the total dpm present. The mean (with SE) rate of breakdown was calculated by a linear regression of these values $v$. incubation time. All observations (ten) were used where the rate of breakdown was $10 \% / \mathrm{h}$ or less. However, more rapid rates gave non-linear graphs at later incubation times, and only values up to a maximum extent of degradation of $40 \%$ were used to calculate these rates. Proteolytic activity was measured in different portions of the same preparations using casein labelled with $\left[{ }^{14} \mathrm{C}\right]$ formaldehyde (Wallace, 1983a). 


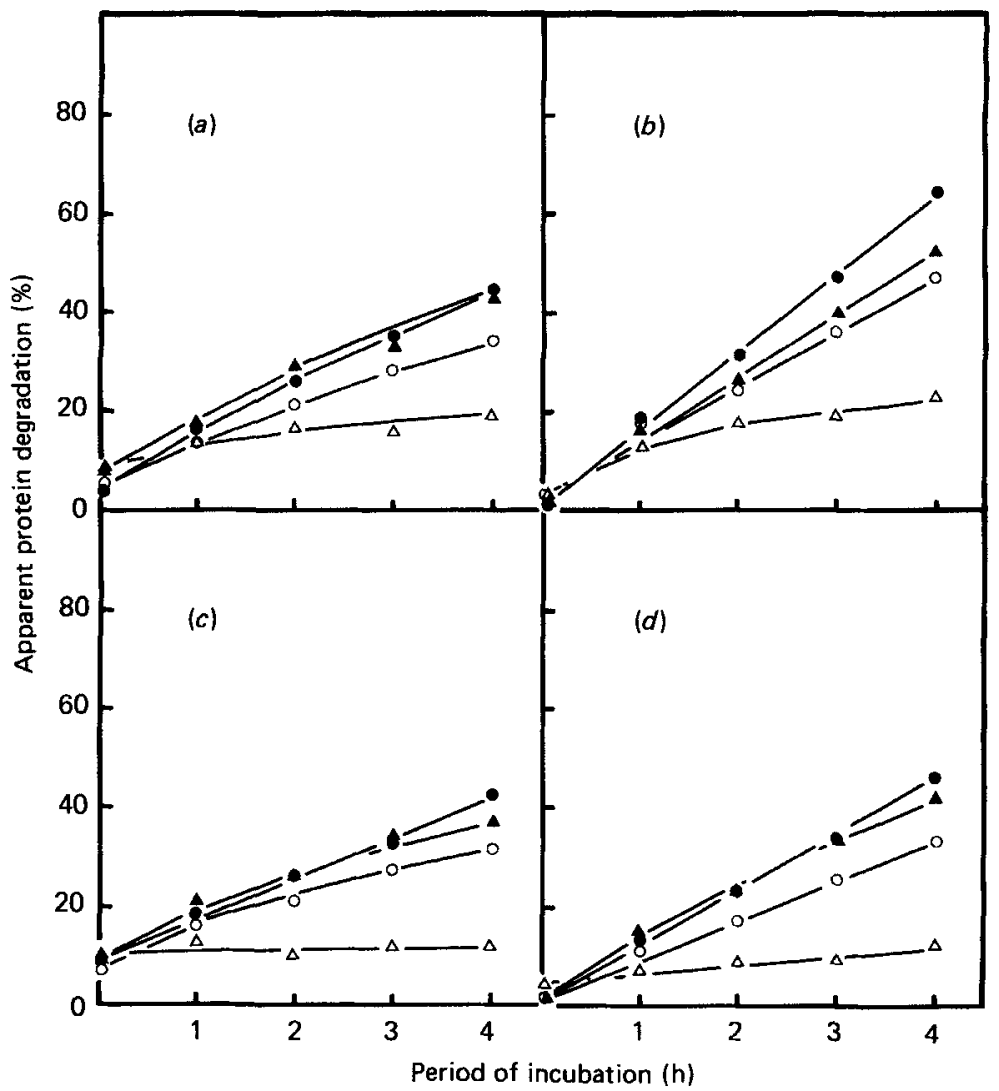

Fig. 1. Breakdown of bacterial protein labelled with different amino acids in strained rumen fluid. (a) Selenomonas ruminantium, sheep no. 288; (b) Megasphaera elsdenii, sheep no. 288; (c) Sel. ruminantium, sheep no. 4061; (d) $M$. elsdenii, sheep no. 4061. The amino acids used to label the bacteria were $\left[{ }^{14} \mathrm{C}\right]$ leucine $(\mathrm{O}, \boldsymbol{O})$ and $\left[{ }^{14} \mathrm{C}\right]$ tyrosine $(\Delta, \boldsymbol{\Delta})$, and turnover was measured in the presence $(\boldsymbol{O}, \boldsymbol{\Delta})$ and absence $(\mathrm{O}, \triangle)$ of $5 \mathrm{~mm}$ of the corresponding unlabelled amino acid. Protozoal counts for sheep no. 288 (sheep no. 4061 in parentheses) were as follows: large entodiniomorphs $5.2(3.0) \times 10^{3} / \mathrm{ml}$, small entodiniomorphs $2 \cdot 1(3 \cdot 2) \times 10^{5} / \mathrm{ml}$, Isotricha spp. $3 \cdot 0(4 \cdot 0) \times 10^{3} / \mathrm{ml}$, Dasytricha $<1(1 \cdot 8) \times 10^{4} / \mathrm{ml}$.

\section{Protozoal counts}

Protozoal counts were done by direct microscopy of formaldehyde preparations (Wallace et al. 1987).

\section{Amino acid estimation}

The rate of disappearance of amino acids was determined by adding solid amino acid to SRF to a final concentration of $5 \mathrm{~mm}$ and incubating at $39^{\circ}$ for up to $5 \mathrm{~h}$. Samples were removed at $1 \mathrm{~h}$ intervals, centrifuged $(49000 \mathrm{~g}, 15 \mathrm{~min})$ and the amino acid content of the supernatant fluid was determined by ion-exchange chromatography (Wallace, 1986).

\section{RESULTS}

\section{Measurement of bacterial protein breakdown}

Release of three different radioactive amino acid labels from the labelled protein of five rumen bacteria incubated in SRF was investigated to determine which was most suitable for the measurement of protein degradation. The rate of release of $\left[{ }^{14} \mathrm{C}\right]$ tyrosine from 


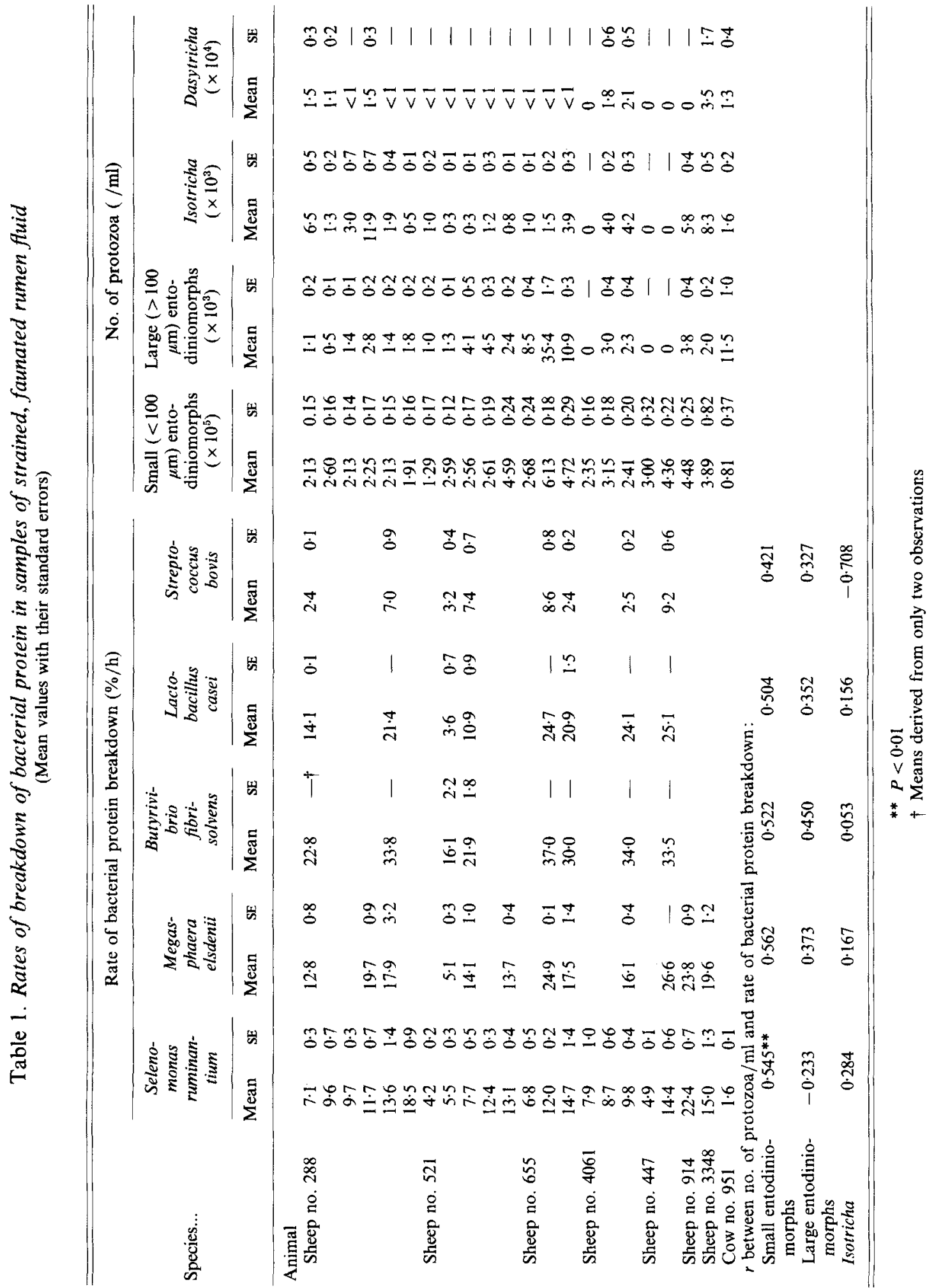


Table 2. Influence of viability on bacterial protein breakdown in strained rumen fluid $(S R F)$

(Pure cultures of rumen bacteria were labelled with $\left[{ }^{14} \mathrm{C}\right]$ leucine and incubated in SRF, either without treatment, or following killing by u.v. irradiation or by autoclaving. Protozoal numbers are given in Table 1. The rates of protein breakdown are expressed as $\% / h$. Values are means with their standard errors)

\begin{tabular}{|c|c|c|c|c|c|c|c|c|c|c|c|c|}
\hline \multirow{3}{*}{ Bacteria... } & \multicolumn{6}{|c|}{ Sheep no. 521} & \multicolumn{6}{|c|}{ Sheep no. 288} \\
\hline & \multicolumn{2}{|c|}{ Live } & \multicolumn{2}{|c|}{ u.v.-treated } & \multicolumn{2}{|c|}{ Autoclaved } & \multicolumn{2}{|c|}{ Live } & \multicolumn{2}{|c|}{ u.v.-treated } & \multicolumn{2}{|c|}{ Autoclaved } \\
\hline & Mean & SE & Mean & $\mathrm{SE}$ & Mean & SE & Mean & SE & Mean & SE & Mean & $\mathrm{SE}$ \\
\hline \multicolumn{13}{|l|}{ Degradation rate $(\% / h)$} \\
\hline Selenomonas ruminantium & $7 \cdot 7$ & $0 \cdot 5$ & 6.5 & 0.6 & $8 \cdot 0$ & $0 \cdot 3$ & 13.6 & 1.4 & $13 \cdot 8$ & 0.6 & $13 \cdot 8$ & 0.9 \\
\hline Streptococcus bovis & $7 \cdot 4$ & 0.7 & $5 \cdot 5$ & $0 \cdot 4$ & $4 \cdot 7$ & 0.5 & $7 \cdot 0$ & 0.9 & $6 \cdot 1$ & 0.7 & $7 \cdot 1$ & $1 \cdot 1$ \\
\hline Megasphaera elsdenii & $14 \cdot 1$ & $1 \cdot 0$ & $13 \cdot 3$ & 1.6 & $13 \cdot 3$ & $1 \cdot 2$ & $17 \cdot 9$ & $3 \cdot 2$ & $14 \cdot 8$ & 0.3 & $15 \cdot 8$ & 0.4 \\
\hline Butyrivibrio fibrisolvens & $21 \cdot 9$ & 1.8 & $21 \cdot 5$ & $0 \cdot 1$ & $23 \cdot 4$ & 0.2 & $33 \cdot 8$ & - & $30 \cdot 2$ & - & $31 \cdot 2$ & - \\
\hline Lactobacillus casei & $10 \cdot 9$ & 0.9 & $7 \cdot 3$ & 0.4 & 6.6 & 0.4 & $21 \cdot 4$ & - & $17 \cdot 1$ & - & $16 \cdot 4$ & - \\
\hline
\end{tabular}

* Based on only two measurements of the initial rate.

labelled Sel. ruminantium and $M$. elsdenii was increased when unlabelled tyrosine was added to the medium and a smaller, similar effect was observed with $\left[{ }^{14} \mathrm{C}\right]$ leucine and unlabelled leucine with these bacteria (Fig. 1). At this concentration of added amino acid $(5 \mathrm{mM})$, the utilization of tyrosine and leucine by SRF was insignificant over the time-scale of the experiment, so an excess of unlabelled amino acid would always be present and reincorporation of released label would not occur. The apparent rate of protein degradation was slightly higher using $\left[{ }^{14} \mathrm{C}\right]$ leucine compared with $\left[{ }^{14} \mathrm{C}\right]$ tyrosine with $M$. elsdenii (Fig. $1(b)$ ), but no significant difference was seen with Sel. ruminantium (Fig. 1(a)) or with Str. bovis, B. fibrisolvens or $l$. casei (not shown). In contrast, $\left[{ }^{14} \mathrm{C}\right]$ phenylalanine gave much lower (on average $38 \%$ of the values found with $\left[{ }^{14} \mathrm{C}\right]$ leucine) apparent breakdown rates with all bacteria, even in the presence of unlabelled $5 \mathrm{~mm}$-phenylalanine, indicating that this label was not suitable for the determination of protein turnover (Mandelstam, 1963). $\left[{ }^{14} \mathrm{C}\right]$ leucine was used to label bacterial protein in subsequent experiments.

\section{Influence of bacterial species and viability on the rate of breakdown of bacterial protein in rumen fluid}

Rates of bacterial protein degradation in different samples of SRF varied from 1.6 to $37 \% / \mathrm{h}$ for different species (Table 1). The ranking order of species was similar in different samples of SRF, with $B$. fibrisolvens always being most rapidly degraded at 28.6 (SE 7.4) \%/h and Str. bovis most slowly degraded at 5.3 (SE 3.0) \%/h. L. casei, M. elsdenii and Sel. ruminantium were broken down at intermediate rates of 18.1 (SE 7.8), 17.7 (SE 6.0) and 10.5 (SE 4.9$) \% / \mathrm{h}$ respectively.

The influence of bacterial viability and cell death on the rate of protein degradation was investigated by killing bacteria by u.v. irradiation or by autoclaving. In the former case, bacteria were non-viable but presumably still metabolically active, since the main effect of u.v. is to damage the cell's DNA. Autoclaving would be expected to destroy all endogenous metabolic activity. Neither treatment had a significant effect on the observed rate of degradation, except for $L$. casei, which was degraded about $4 \% / \mathrm{h}$ more slowly if cells were non-viable (Table 2). 
Table 3. Bacterial protein turnover in rumen fluid from ciliate-free sheep

(Mean values with their standard errors)

\begin{tabular}{|c|c|c|c|c|c|c|}
\hline & \multicolumn{6}{|c|}{ Degradation rate $(\% / h)$} \\
\hline & \multicolumn{2}{|c|}{ SRF } & \multicolumn{2}{|c|}{ CFRF } & \multicolumn{2}{|c|}{$\begin{array}{c}\text { Anaerobic } 50 \mathrm{~mm}- \\
\text { phosphate buffer, } \mathrm{pH} \\
7.5\end{array}$} \\
\hline & Mean & SE & Mean & SE & Mean & SE \\
\hline \multicolumn{7}{|l|}{ Sheep no. 72} \\
\hline Selenomonas ruminantium & 0.53 & 0.06 & $0 \cdot 32$ & $0 \cdot 11$ & $1 \cdot 06$ & 0.46 \\
\hline Streptococcus bovis & 0.23 & 0.09 & 0.43 & $0 \cdot 19$ & 0.50 & 0.32 \\
\hline Megasphaera elsdenii & $2 \cdot 25$ & 0.43 & $3 \cdot 15$ & $0 \cdot 12$ & 0.08 & 0.04 \\
\hline Butyrivibrio fibrisolvens & $1 \cdot 13$ & 0.36 & $1 \cdot 14$ & $0 \cdot 16$ & 0.39 & $0 \cdot 17$ \\
\hline Lactobacillus casei & $0 \cdot 40$ & $0 \cdot 23$ & 1.43 & $0 \cdot 25$ & 0.97 & $0 \cdot 13$ \\
\hline \multicolumn{7}{|l|}{ Sheep no. 92} \\
\hline Selenomonas ruminantium & 0.98 & $0 \cdot 16$ & 0.37 & 0.08 & $1 \cdot 22$ & 0.21 \\
\hline Streptococcus bovis & $0 \cdot 28$ & 0.45 & 0.47 & 0.01 & 0.24 & $0 \cdot 12$ \\
\hline Megasphaera elsdenii & $2 \cdot 74$ & 0.46 & $2 \cdot 66$ & $0 \cdot 25$ & 0.34 & 0.04 \\
\hline Butyrivibrio fibrisolvens & 0.85 & 0.20 & 0.55 & 0.06 & 0.42 & 0.05 \\
\hline Lactobacillus casei & 0.35 & 0.06 & 1.48 & $0 \cdot 16$ & 0.68 & 0.44 \\
\hline
\end{tabular}

SRF, strained rumen fluid; CFRF, cell-free rumen fluid.

Evaluation of possible causes of bacterial protein turnover

The finding that the labelled protein of autoclaved bacteria was in general degraded at rates similar to live bacteria (Table 2) suggested that factors other than those associated with endogenous metabolic activities were mainly responsible for bacterial protein turnover. Incubation of $\left[{ }^{14} \mathrm{C}\right]$ leucine-labelled bacteria in buffer containing an excess of unlabelled leucine (Table 3) resulted in low rates of protein degradation which confirmed that endogenous protein turnover was not a major consideration.

Centrifugation of SRF to remove protozoa and large particles caused an average decrease of $88 \%$ in the bacterial protein degradation rate (Table 4). Further removal of all particulate material, including bacteria, resulted in a further small decrease in the observed rate, to values of about $1 \% / \mathrm{h}$ or less (Tables $4-6$ ), similar to the rates due to endogenous turnover.

Similar experiments with ciliate-free sheep (Table 3) showed that the rates of bacterial protein degradation occurring in SRF containing large particles but free of protozoa were low. These rates were of the same order as the turnover rates observed when labelled bacteria were suspended in buffer, except for $M$. elsdenii, which lost label more rapidly in the presence of SRF or CFRF from ciliate-free sheep (Table 3). Lower degradation rates were found for M. elsdenii in CFRF from faunated sheep (Tables 4-6), and the rate of protein breakdown in ciliate-free SRF was in any case much less than that found with faunated rumen fluid. From these results it was concluded that a high rate of bacterial protein degradation was found only in samples which contained ciliate protozoa.

Relation between bacterial protein turnover and the population of ciliate protozoa

The health of the ciliate protozoa was monitored carefully throughout all of these experiments. Samples of rumen fluid were always kept at $39^{\circ}$, and the rate of shaking during incubations was always the minimum consistent with keeping protozoa in suspension. As 
Table 4. Bacterial protein degradation by different fractions of rumen fluid from sheep no. 655

(Mean values with their standard errors)

\begin{tabular}{|c|c|c|c|c|c|c|}
\hline \multirow{3}{*}{$\begin{array}{l}\text { Fraction... } \\
\text { Species }\end{array}$} & \multicolumn{6}{|c|}{ Degradation rate $(\% / h)$} \\
\hline & \multicolumn{2}{|c|}{$\mathrm{SRF}^{*}$} & \multicolumn{2}{|c|}{ PFRF } & \multicolumn{2}{|c|}{ CFRF } \\
\hline & Mean & $\mathrm{SE}$ & Mean & $\mathrm{SE}$ & Mean & SE \\
\hline Selenomonas ruminantium & $14 \cdot 7$ & $1 \cdot 4$ & $2 \cdot 1$ & 0.8 & $0 \cdot 2$ & 0.2 \\
\hline Streptococcus bovis & $2 \cdot 4$ & 0.2 & $0 \cdot 3$ & $0 \cdot 1$ & $0 \cdot 1$ & $0 \cdot 1$ \\
\hline Megasphaera elsdenii & $17 \cdot 5$ & $1 \cdot 4$ & $2 \cdot 9$ & 0.4 & $1 \cdot 1$ & 0.2 \\
\hline Butyrivibrio fibrisolvens & $30 \cdot 0$ & $-\dagger$ & $2 \cdot 0$ & 0.5 & $1 \cdot 0$ & 0.3 \\
\hline Lactobacillus casei & $20 \cdot 9$ & 1.5 & 1.5 & 0.3 & $1 \cdot 0$ & 0.2 \\
\hline
\end{tabular}

SRF, strained rumen fluid; PFRF, protozoa-free rumen fluid; CFRF, cell-free rumen fluid.

* Nos. of protozoa per ml SRF were 10.9 (SE 0.3) $\times 10^{3}$ large entodiniomorphs, 4.72 (SE 0.29) $\times 10^{5}$ small entodiniomorphs, 3.9 (SE 0.3) $\times 10^{3}$ Isotricha and $<10^{4}$ Dasytricha.

$\dagger$ Based on only two measurements of the initial rate.

Table 5. Breakdown of bacterial protein by washed protozoa and cell-free rumen fluid $(C F R F)$

(A suspension of washed protozoa was obtained from strained rumen fluid (SRF) taken from sheep no. 521, and samples of SRF, washed protozoa and CFRF were incubated with labelled species of rumen bacteria to determine protein degradation as described on p. 314 . Values are means with their standard errors)

\begin{tabular}{|c|c|c|c|c|c|c|}
\hline \multirow[b]{3}{*}{ Species } & \multicolumn{6}{|c|}{ Degradation rate $(\% / h)$} \\
\hline & \multicolumn{2}{|c|}{ SRF } & \multicolumn{2}{|c|}{ Washed protozoa } & \multicolumn{2}{|c|}{ CFRF } \\
\hline & Mean & SE & Mean & SE & Mean & SE \\
\hline Selenomonas ruminantium & 5.5 & $0 \cdot 3$ & $9 \cdot 6$ & $1 \cdot 3$ & $0 \cdot 3$ & 0.2 \\
\hline Streptococcus bovis & $3 \cdot 2$ & $0 \cdot 4$ & $7 \cdot 8$ & 0.6 & 0.5 & $0 \cdot 1$ \\
\hline Megasphaera elsdenii & $5 \cdot 1$ & $0 \cdot 3$ & $4 \cdot 1$ & $0 \cdot 3$ & 0.5 & 0.2 \\
\hline Butyrivibrio fibrisolvens & $16 \cdot 1$ & $2 \cdot 2$ & $14 \cdot 0$ & $4 \cdot 3$ & 0.8 & 0.3 \\
\hline Lactobacillus casei & 3.6 & $0 . \overline{7}$ & $6 \cdot 7$ & 0.5 & $0 \cdot 4$ & $0 \cdot 1$ \\
\hline \multicolumn{7}{|l|}{ Protozoal numbers } \\
\hline Large entodiniomorphs $\left(\times 10^{3}\right)$ & $1 \cdot 3$ & $0 \cdot 1$ & $12 \cdot 0$ & $2 \cdot 4$ & 0 & 0 \\
\hline Small entodiniomorphs $\left(\times 10^{5}\right)$ & $2 \cdot 59$ & $0 \cdot 12$ & $1 \cdot 13$ & $0 \cdot 49$ & 0 & 0 \\
\hline Isotricha $\mathrm{sp} .\left(\times 10^{3}\right)$ & $0 \cdot 3$ & $0 \cdot 1$ & $1 \cdot 3$ & $0 \cdot 4$ & 0 & 0 \\
\hline
\end{tabular}

a result, the protozoa appeared by microscopic examination to be as healthy and apparently normal at the end of the incubations as at zero time.

An experiment in which washed protozoa were prepared from SRF (Table 5) illustrated that the ciliates were capable of carrying out the degradation of bacterial protein at rates of the same order as those found in SRF. The protozoa were prepared from 1 litre SRF, and, in order to obtain suspensions of ciliates free from contaminating particles, most of the protozoa were discarded during the washing procedure. An enrichment of the fastersedimenting large protozoa also occurred. Conditions were also different in the incubations with SRF and in those with the protozoal suspensions, since a large excess of mixed rumen bacteria was present in the former samples, while the only bacteria present in the latter assays were the labelled bacteria. Nevertheless, it was clear that ciliate protozoa could carry 
Table 6. Breakdown of Selenomonas ruminantium and Megasphaera elsdenii protein and the proteolytic activity of strained $(S R F)$ or cell-free $(C F R F)$ rumen fluid from faunated sheep

(Mean values with their standard errors)

\begin{tabular}{|c|c|c|c|c|c|c|c|c|c|c|c|c|}
\hline \multirow{4}{*}{$\begin{array}{l}\text { Fraction... } \\
\text { Sheep no. }\end{array}$} & \multicolumn{6}{|c|}{$\mathrm{SRF}^{*}$} & \multicolumn{6}{|c|}{ CFRF } \\
\hline & \multirow{2}{*}{\multicolumn{2}{|c|}{$\begin{array}{l}\text { Proteolytic } \\
\text { activity } \dagger\end{array}$}} & \multicolumn{4}{|c|}{$\begin{array}{l}\text { Bacterial protein breakdown } \\
\qquad(\% / \mathrm{h})\end{array}$} & & & \multicolumn{4}{|c|}{$\begin{array}{c}\text { Bacterial protein breakdown } \\
(\% / \mathrm{h})\end{array}$} \\
\hline & & & \multicolumn{2}{|c|}{$\begin{array}{l}\text { Sel. rumin- } \\
\text { antium }\end{array}$} & \multicolumn{2}{|c|}{ M. elsdenii } & \multicolumn{2}{|c|}{$\begin{array}{l}\text { Proteolytic } \\
\text { activity } \dagger\end{array}$} & \multicolumn{2}{|c|}{$\begin{array}{l}\text { Sel. rumin- } \\
\text { antium }\end{array}$} & \multicolumn{2}{|c|}{ M. elsdenii } \\
\hline & Mean & SE & Mean & SE & Mean & $\mathrm{SE}$ & Mean & $\mathrm{SE}$ & Mean & $\mathrm{SE}$ & Mean & SE \\
\hline 914 & 1.99 & 0.06 & $22 \cdot 4$ & $3 \cdot 8$ & $23 \cdot 8$ & 0.9 & 1.42 & 0.04 & 0.1 & 0.2 & 0.7 & $0 \cdot 1$ \\
\hline 521 & 1.83 & 0.05 & $13 \cdot 1$ & $0 \cdot 4$ & $13 \cdot 7$ & $0 \cdot 4$ & 0.57 & 0.01 & 0.4 & 0.1 & 0.4 & 0.1 \\
\hline 288 & $2 \cdot 18$ & 0.02 & $11 \cdot 7$ & 0.7 & $19 \cdot 7$ & 0.9 & $0 \cdot 91$ & 0.03 & 0.2 & 0.1 & 0.5 & $0 \cdot 1$ \\
\hline 3348 & $2 \cdot 46$ & 0.03 & $15 \cdot 0$ & $1 \cdot 3$ & $19 \cdot 6$ & $1 \cdot 2$ & 0.95 & $0 \cdot 04$ & $0 \cdot 1$ & $0 \cdot 1$ & 0.6 & $0 \cdot 1$ \\
\hline
\end{tabular}

* Protozoal numbers are given in Table 1.

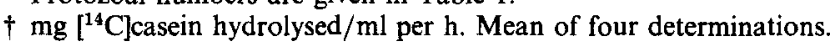

out degradation of bacterial protein at rates sufficient to account for the rates observed in SRF. Furthermore, removal of all particles from SRF resulted in rates of protein breakdown (Tables 4, 5) of the same order as those found in CFRF from ciliate-free sheep, indicating that all the degradative activity was associated with intact protozoal cells.

The rates of bacterial protein degradation in SRF and CFRF were compared with the corresponding proteolytic activities of the same fractions (Table 6). Again, removal of all particles caused most ( $97 \%$ or more) of the activity towards bacterial protein to be lost, whereas an average of only $64 \%$ of the proteolytic activity towards casein was sedimented.

The numbers of ciliate protozoa were determined in all the samples of SRF used in these incubations. Straining rumen fluid removes the organisms most closely associated with food particles, so the protozoal populations in SRF need not be representative in either numbers or composition of the ciliate population in the original rumen fluid. Nevertheless, a direct comparison of the numbers present in different samples of SRF and the corresponding degradation rates can provide useful information on the role of protozoa (Table 1). No correlation was found between the numbers of large protozoa and the observed rate of degradation of any of the five bacterial species. The only significant correlation was found between the rate of degradation of Sel. ruminantium and the numbers of small entodiniomorphid protozoa (Table 1). A great deal of scatter was observed in a plot of the results (Fig. 2). A smaller number of samples was used to investigate the degradation of $M$. elsdenil, and the correlation with the numbers of small entodiniomorphs was only significant at $P<0.1$ (Table 1). The relation for the smaller numbers of determinations for the other species did not reach significance, although a similar trend was apparent.

\section{DISCUSSION}

The aim of the present study was to quantify the factors that lead to the breakdown, and hence turnover, of bacterial protein in the rumen. In earlier studies, Jarvis (1968) used a Butyrivibrio sp. and Str. bovis labelled with $\left[{ }^{3} \mathrm{H}\right]$ thymidine in incubations with rumen fluid to measure the rate of cell death and lysis of these bacteria. Any component of endogenous 


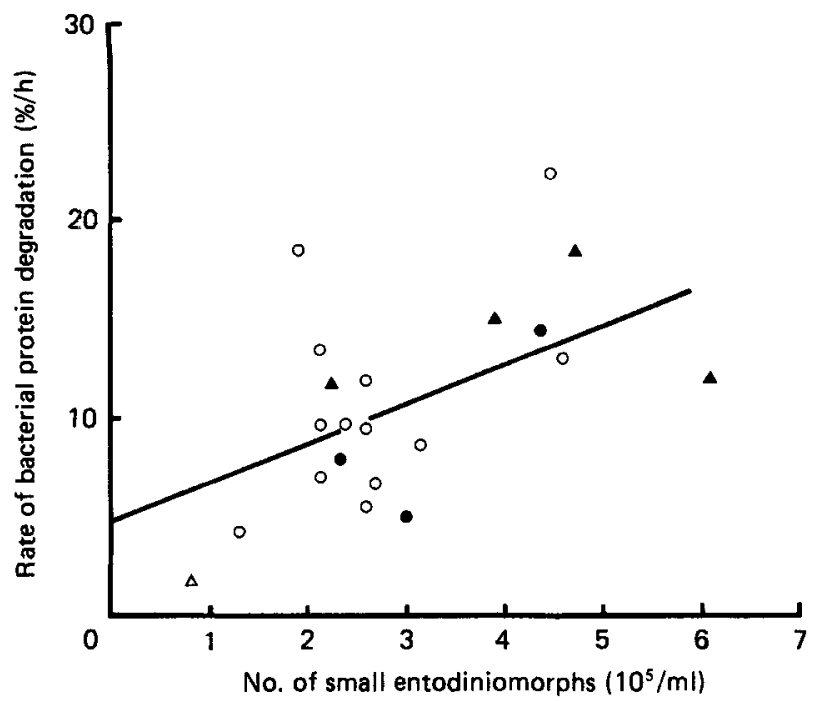

Fig. 2. Relation between the rate of breakdown of bacterial protein and numbers of small $(<100 \mu \mathrm{m})$ entodiniomorphid protozoa in rumen fluid. $\left[{ }^{14} \mathrm{C}\right]$ leucine-labelled Selenomonas ruminantium was incubated in vitro with samples of strained rumen fluid from different sheep containing mixed populations of large and small entodiniomorphs and holotrichs in which large protozoa were present at $>10^{4} / \mathrm{ml}(\mathbf{A})$, at $<10^{4} / \mathrm{ml}(\mathrm{O})$, or were absent $(\mathbf{O})$. A sample of bovine rumen fluid, containing $1.3 \times 10^{4}$ large protozoa $/ \mathrm{ml}$ (predominantly Epidinium) was included $(\triangle)$.

turnover, not leading to cell lysis, was not determined. Hoogenraad \& Hird (1970) and Hoogenraad et al. (1970) labelled bacteria with $\left[{ }^{14} \mathrm{C}\right] g l u c o s e$ and so measured total cell breakdown, but the bacteria used were facultative anaerobes not typical of the normal rumen flora. The present work describes the breakdown specifically of bacterial protein, due to both cell death and endogenous turnover in common species of rumen bacteria, when incubated in different samples of SRF.

Bacteria labelled with $\left[{ }^{14} \mathrm{C}\right]$ leucine were incubated in vitro with rumen fluid to which was added an excess of unlabelled amino acid to prevent re-incorporation of released label. This technique is often used to study bacterial endogenous protein turnover, and it can also be used to determine protein breakdown by exogenous factors. It is invariably an imperfect method for measuring turnover, however, as it depends on complete equilibration of all intra- and extracellular amino acid pools, which does not always occur and so can give a falsely low apparent rate (Mandelstam, 1963). The high concentration of chaser amino acid may furthermore alter the regulation of intracellular proteolysis (Pine, 1972). Two different amino acid labels used in the present study gave essentially similar apparent rates of breakdown with each of the different bacterial species, so it was concluded that this estimate of turnover was probably correct. However, there can be no certainty of this. Since our conclusions are based on comparative, rather than absolute, values, it is unlikely that any minor systematic error in measuring turnover would affect their validity.

Several different types of experiment indicated that high rates of bacterial protein turnover occurred only in the presence of ciliate protozoa. When protozoa and other large particles were removed by centrifugation, protein breakdown of five species of rumen bacteria in rumen fluid decreased by an average of $88 \%$ (Table 4). Parallel experiments with ciliate-free, but otherwise similar, sheep showed that the rate of bacterial protein breakdown in non-faunated rumen fluid was on average only $6.4 \%$ of that found in faunated samples (Table 3 ). It should be noted here that the ciliate-free animals were 
obtained by isolation at birth rather than by chemical treatment, thus eliminating any ambiguity due to the possible toxic effects of chemicals on the background flora. Further experiments with faunated sheep demonstrated that protozoa alone could degrade bacterial protein at rates similar to those found in the whole population (Table 5).

The rate of bacterial protein breakdown in the absence of protozoa was much less than might have been expected from reports of soluble lytic factors (Jarvis, 1968) and of extensive autolysis (Hoogenraad \& Hird, 1970) in rumen contents. No evidence of such phenomena was found in the animals studied here (Tables 3-6), except for a very minor lytic effect of ciliate-free rumen fluid on $M$. elsdenii (Table 3). Moreover, endogenous protein turnover, as measured by the rate of protein breakdown of bacteria suspended in anaerobic buffer, was lower than that found with some other bacteria (Pine, 1972), but enough to account for most of the protein turnover seen in the absence of protozoa (Table 3). When endogenous turnover was eliminated by autoclaving labelled bacteria before the incubation in SRF, no difference was observed in the rate of breakdown of four of the five bacterial species examined (Table 2), again suggesting that this metabolic activity was relatively insignificant. Even with the fifth species, L. casei, the effect was minor.

The absolute absence or presence of protozoa, therefore, has a major influence on the rate at which bacterial protein breaks down in rumen fluid. The size and composition of the protozoal population might then be expected to determine the magnitude of the effect. The samples used in the present study each contained a unique population of protozoa consisting of many different species. In an attempt to simplify the number of variables, we classified the ciliates present into large and small entodiniomorphs and large and small holotrichs. Obviously the first two categories may contain widely different numbers of quite dissimilar organisms, and hence completely different metabolic activities despite similar numbers. No correlation was observed between numbers of large protozoa or Dasytricha and the rate of bacterial protein degradation, but, despite their heterogeneity, a trend was observed linking the numbers of small entodiniomorphid protozoa and the rate of bacterial protein degradation (Table 1, Fig. 2). The best-fitting line from Fig. 2 is equivalent to an average rate of degradation of Sel. ruminantium protein of $2 \% / \mathrm{h}$ per $10^{5}$ protozoa per $\mathrm{ml}$. If the total bacterial population was $5 \times 10^{9} / \mathrm{ml}$, the rate of uptake of bacteria per protozoon would be $\left(0 \cdot 02 \times 5 \cdot 10^{9}\right) / 10^{5}=10^{3} / \mathrm{h}$, a value of the same order as that found by Coleman (1980) with most axenic cultures of protozoa.

The protein of different species of bacteria was degraded at different rates in the same samples of rumen fluid, but the ranking order of the bacterial species was similar to different samples with greatly different protozoal populations. Bacterial size or shape did not appear to determine the rate of degradation. Str. bovis was most stable in all samples of faunated SRF examined, and $B$. fibrisolvens was most actively degraded. A slightly different pattern was observed with washed protozoa, perhaps reflecting different preferences when labelled bacteria were present as the only bacterial prey rather than in the presence of an excess of mixed rumen bacteria. However, $B$. fibrisolvens remained the least stable organism (Table 5). Coleman (1980) reviewed the properties of protozoa, and their apparently selective engulfment of different bacterial species. In the present experiments with SRF, selection by the protozoa of different labelled bacteria added to a much larger population of mixed bacteria seems unlikely. Different susceptibilities to breakdown probably reflect only the intrinsic resistance of different species to physical or enzymic breakdown. B. fibrisolvens would be expected to be most vulnerable, as was observed here, due to its thin cell wall (Cheng \& Costerton, 1977). Breakdown was not simply due to proteolytic attack, judging by the lack of correlation between turnover and the proteolytic activity of rumen fluid (Table 6). Str. bovis, for example, is highly resistant to proteolytic attack (Wallace, $1983 \mathrm{~b}$ ) but is rapidly broken down by proteases if treated with the cell wall 
hydrolase, mutanolysin (S. A. B. Knight and R. J. Wallace, unpublished experiments). Protozoa therefore presumably contain similar cell wall hydrolases essential for exposing bacterial cytoplasmic contents to proteolytic attack.

Based on the results presented here, one might expect defaunation to be of great benefit to the efficiency of microbial protein synthesis in the rumen, by avoiding wasteful protein turnover (Leng \& Nolan, 1984). Enhancement of the microbial growth yield by defaunation has been observed both in vitro (Demeyer \& Van Nevel, 1979) and in vivo (Ushida et al. 1986). However, the finding that defaunation is actually of little benefit in vivo unless dietary protein is exceptionally low (Leng \& Nolan, 1984; Rowe et al. 1985) implies that other influences, such as on the rate of fibre degradation (Demeyer, 1981), intervene to counteract the advantageous one of removing the most important cause of microbial protein turnover in rumen fluid.

The authors thank Margaret L. Brammall for technical assistance and J. M. Eadie and W. J. Shand for the use of ciliate-free sheep and the preparation of washed protozoal suspensions.

\section{REFERENCES}

Cheng, K.-J. \& Costerton, J. W. (1977). Journal of Bacteriology 129, 1506-1512.

Coleman, G. S. (1979). Tropical Animal Production 4, 199-213.

Coleman, G. S. (1980). Advances in Parasitology 18, 121-173.

Demeyer, D. (1981). Agriculture and Environment 6, 295-337.

Demeyer, D. \& Van Nevel, C. J. (1979). British Journal of Nutrition 42, 515-524.

Eadie, J. M. \& Gill, J. C. (1971). British Journal of Nutrition 26, 155-167.

Hobson, P. N. (1969). Methods of Microbiology 3B, 133-149.

Hobson, P. N. \& Wallace, R. J. (1982). Critical Reviews in Microbiology 9, 253-320.

Hoogenraad, N. J. \& Hird, F. J. R. (1970). Journal of General Microbiology 62, 261-264.

Hoogenraad, N. J., Hird, F. J. R., Holmes, I. \& Millis, N. F. (1967). Journal of General Virology 1, 575--576.

Hoogenraad, N. J., Hird, F. J. R., White, R. G. \& Leng, R. A. (1970). British Journal of Nutrition 24, 129-144. Jarvis, B. D. W. (1968). Applied Microbiology 16, 714-723.

Leng, R. A. \& Nolan, J. V. (1984). Journal of Dairy Science 67, 1072-1089.

Lindsay, J. R. \& Hogan, J. P. (1972). Australian Journal of Agricultural Research 23, 321-330.

Mandelstam, J. (1963). Annals of the New York Academy of Sciences 102, 621-636.

Orpin, C. G. \& Munn, E. A. (1974). Experientia 30, 1018-1020.

Pine, M. J. (1972). Annual Review of Microbiology 26, 103-126.

Robinson, J. P. \& Hungate, R. E. (1973). International Journal of Systematic Bacteriology 23, 171-181.

Rowe, J. B., Davies, A. \& Broome, A. W. J. (1985). British Journal of Nutrition 54, 105-119.

Scott, H. W. \& Dehority, B. A. (1965). Journal of Bacteriology 89, 1169-1175.

Ushida, K., Jouany, J. P. \& Thivend, P. (1986). British Journal of Nutrition 56, 407-419.

Wallace, R. J. (1983a). British Journal of Nutrition 50, 345-355.

Wallace, R. J. (1983b). British Journal of Nutrition 49, 101-108.

Wallace, R. J. (1986). Applied and Environmental Microbiology 51, 1141-1143.

Wallace, R. J., Broderick, G. A. \& Brammall, M. L. (1987). British Journal of Nutrition 58, 87-93.

Whitelaw, F. G., Bruce, L. A., Eadie, J. M. \& Shand, W. J. (1983). Applied and Environmental Microbiology 46, 951-953. 